UNTAG Law Review (ULREV)

Volume 1, Issue 2, Nov 2017, PP 69-76

ISSN 2549-4910 (online) \& ISSN 2579-5279 (print)

http://jurnal.untagsmg.ac.id/indeks.php/ulrev/indeks

www.fakhukum.untagsmg.ac.id

\title{
DISTRIBUTION OF HERITAGE AND CULTURE IDDAH MINANG DIVORCE IN WHICH IMPLEMENTED IN THE LAW NUMBER 1 YEAR 1974 ON MARRIAGE
}

\author{
Putri Maha Dewi
}

Student of Doctoral Sebelas Maret University can info by email: maha.dewie21@gmail.com

\begin{abstract}
Divorce is the dissolution, which has been fostered by married couples caused by several things such as death and the decision of justice. In this case the divorce is seen as the end of an instability of marriage where married couples live apart and Seara then officially recognized by applicable law. In Act No. 1 1974, namely Article 11 (1) For a valid marriage that broke up the waiting period. (2) The period of time the waiting period of paragraph (1) shall be regulated further in a government regulation. In indigenous cultures also known'Iddah Minang, the waiting period for a woman whose divorce from her husband to be able to mate again, in order to know whether women are pregnant or not. If the woman was pregnant, then he is allowed to marry again after her son was born, when she was not pregnant, then she had to wait 4 months 10 days and if divorced because the husband dies or 3 times the holy of menstruation if life due to divorce. While traditional Minang cultural heritage division contrary to the division of inheritance according to Law No. 1 Year 1974 about marriage. In a culture known as the Minang traditional matrilineal system thus indirectly all the treasures bequeathed to the daughter. In Act No. 1 of 1974 on Marriage, inheritance is the joint property.
\end{abstract}

Keywords: Treasure inheritance, the prescribed period, Divorce, Minang Culture

\section{INTRODUCTION}

In every society the kinship arrangement however, the marriage will require adjustments in many ways. Marriage raises new relationship not only between the individual concerned, between marapulai and virgin but also between the two families. Background between these two very different refractive Daik family origins, habits, education, social level, manners, language and so forth. Because the main requirements that must be met in a marriage, the willingness and capability to adjust from each party. Introduction and approach to get to know the character of each individual and family is very important to obtain harmony or harmony in relationships between family soon afterwards. ${ }^{1}$

Marriage also requires a sense of responsibility, these include the inner and outer living, life assurance and responsibility education children who will be born. Twisting both between customs and the religion of Islam in Minangkabau carries its own consequences.

1 Riduan Syahrani, 1989, The Inside and Principles of Civil Law, CV Alumni, Bandung, Pg 89. 
Both provisions adaat, as well as religious requirements in regulating life and Minang community life, can not be ignored, especially in the implementation of marriage. Both rules that must be studied and implemented in a manner harmonious and consistent along.

Divorce terminology derived from the word divorce means separation, and then gets the prefix per functioning forming objects abstract word then becomes divorce, which means the result of a divorce action. the principle of marriage in the Marriage Act, the purpose of marriage is to establish a happy family and eternal marriage should break because of the divorce must be banned, but in reality the Marriage Act did not confirm about the ban, but enough to embarrass a divorce that decides marriage. ${ }^{2}$

In marriage, divorce is an event that sometimes can not be avoided by married couples, whether they are newly married or who had been married long. Divorce is one of the reasons he decided matrimony out other causes of death and or the court's decision as contained in Article 38 of the Marriage Law. In the case of divorce can be done and decide if it has its reasons, both the husband and wife.

Divorce by Subekti is the elimination of the marriage with the judge's ruling or the demands of one of the parties in the marriage. ${ }^{3}$ However, Subekti not express the notion of divorce as the elimination of the marriage by death or referred to under the term "divorce die".

Violations let alone a break-in to one of the customary provisions and norms of Islam in matters of marriage, will bring the bitter consequences of lifelong and sustainable even with the descendants. The sentence imposed indigenous peoples and religions, though never enacted very severe and sometimes much more severe than the penalty imposed Islamic Court and District Court. The punishment was not apparent in the form of exclusion and alienation from society Minang community. Therefore in marriage Minang people always trying to meet all the requirements of marriage prevalent in Minang. ${ }^{4}$

In the event of divorce, the husband had to go home to his wife. Wife while still living at home with the child-anaknyasebaimana residence has been set customary law. When his wife dies, the husband's family obligation to immediately pick up the husband who had become a widower, to be brought back into the environment of his tribe or return to the homeland. The situation is indeed very sad, but that's customary provisions Minang.

In lairiyah and spiritual who have homes in Minang women and men just hitchhike. Minang men's shelter is surau. But this is the source of the dynamics of Minang men, so they become a formidable nomads. This fact is accepted by almost all citizens Minang, both of which occupy the Tower House of traditional and modern homes, either living in hometowns and wandered in the big city. In the traditional structure minang husband position as dating (Urang Sumando) is very weak. While the position of the boy, physically did not have a place at home mother. If something happens in his own household, he no longer had a place to stay. This kind of situation is logically encourage Minang men for trying to be a good person to be respected by his own son and the family of his wife. ${ }^{5}$

Terms of transfer of property of the deceased person to the living is their relationship or kinship greetings determined by blood ties and perkwinan. A child born to a mother having a

2 H. Rusdi Malik, 2010, Understanding the Marriage Act, Jakarta: Universitas Trisakti, p. 89

3 Subekti, 1985, Principal-Principal Civil Law,(Jakarta: PT. Internusa,), 42.

4 Https://bundokandung.wordpress.com/2010/01/31/hukum-adat-di-minangkabau/14/06/201611:12

5 https://www.boyyendratamin.com/2013/02/antara-adat-minangkabau-dan-hukum-adat.html14/06/2016 12:02 
relative relationship with the birth mother. With the enforcement of the relationship kinship lines formed by the mother (matrilineal). Based on the marital relationship, then the wife is heir to her husband and the husband is heir to her. Applicability of inheritance relationship between husband and wife to be based has it took place between legitimate marriage ceremony.

\section{PROBLEMFORMULATION}

Based on the background of the above problems, it can be the formulation of the problem is: "WHAT IS THE DISTRIBUTION OF HERITAGE AND CULTURE 'Iddah MINANG DIVORCE IN WHICH implemented in the LAW NUMBER 1 YEAR 1974 ON MARRIAGE?"

\section{LITERATURE}

Law No. 1 In 1974, Article 11 (1) For a valid marriage that broke up the waiting period. (2) The period of time the waiting period of paragraph (1) shall be regulated in Government Regulation further explains that a wife has a waiting period after divorce is said'Iddah Minang community is helpful to know whether women were pregnant or not after a divorce. If so, then caught her biological father. If his daughters, then (if still alive) he must be a guardian when his son married. Article 38,39,40,42 divorce procedure described on divorce to inheritance.

In the community there (village) kinship was still running, then any dispute should be resolved marital settlement by relatives so that they can get along well. Except where relatives can not finish it then forwarded to the court official

Article 35,36, 37 about the inheritance of rulers we will gain a sense that in a marriage are two kinds of property categories that innate property (Article 35, paragraph 2), for example; demise. And community property (article 35 paragraph 1 ) that the property acquired during the marriage took place. Against the innate property, Law No. 11974 says that each party has the right and to set them on their own. Because of the innate property not included in the joint property in marriage. ${ }^{6}$

Establishment of a happy family was closely connected with the descent, where the maintenance and education of children the rights and duties of parents. Thus the purpose of marriage according to the legislation is to conjugal happiness, to obtain offspring and uphold the religious, the family unit is parental (all the parent's). It which means tighter of destination marriages under customary law that society embraces kinship system that is patrinial (all the father's) such as the Batak, Lampung, Bali, and so on. ${ }^{7}$

The purpose of marriage for indigenous and tribal peoples who are kinship is to maintain and continue the descent line or the paternal or maternal to paternal domestic happiness family / relatives, to acquire indigenous cultural values of peace, and to maintain the inheritance. ${ }^{8}$

In this case contrary to the customary law of inheritance in Minang. They use the matrilineal system of dividing the inheritance in the drop of the maternal lineage. But let a divorce take place only as the last resort after every effort has been made to repair and maintain the marital life. In other words, divorce is a way out emergency exit for a husband and wife for the happiness that can be expected after the divorce.

6 Http://www.hukumonline.com/klinik/detail / t4f3b41b9d2da / impact-divorce-to-treasure-together15/06/2016 12:30

7 Hilman Hadikusuma, 2007, the Marriage Law of Indonesia, Bandung: PT. Mandar Maju, pp 21.

8 ibidp 22 
A marriage if they do not find happiness and peace, or may even cause problems as well as much of the pleasure of God, then it is understandable that the marriage must end, but the divorce was not considered easy, because divorce does not allow if so within marriage only occurs fuss-fuss or problem just a small problem. New divorce allowed if there had been problems are very complex or very principle in the household. On the one hand, divorce is actually allowed in Islam, but on the other hand, marriage is oriented as forever and eternal commitment.

When the quarrel between the two sides, Islam does not directly advocate a husband and wife to end a marriage, but it is done first deliberation. Divorce can only be done in front of the Court of Justice after the concerned court and unsuccessfully tried to reconcile the two sides. To do divorce there must be sufficient grounds, that between husband and wife will not be able to live in harmony as husband and wife. In case of divorce, the mother is having difficulty concrete in dealing with children, while the father had difficulty in early stages of thinking, contemplating her how to handle this situation.

\section{DISCUSSION}

According to the forecast before the enactment of Act 1 of 1974 among the Javanese and Sundanese that are customary parental kinship with a form of free marriage (separate, exit, self-contained) a lot of divorce. Similarly, among the people of Minang properties matrilineal kinship with a form of marriage by marriage is not so much the case of divorce.

According to Article 38 of Law No. 1 of 1974 is a divorce is breaking marred. As for is a marriage is inner and outer bond between a man with a woman as husband and wife in order to establish a happy and eternal family by Belief in God One. ${ }^{9}$ Thus, divorce is a physically and mentally severing of ties between husband and wife which resulted in termination of a family relationship between the husband and wife.

Background and purpose of divorce can be understood that in carrying out the marital life of course not always be in a situation that is peaceful and serene, but sometimes also a misunderstanding between husband and wife so wrong it becomes protracted and can not be reconciled. If a marriage so continued, it is feared a split between husband and wife will lead to a split between the tin rheology divorce as a way out of the last for the husband and wife who had failed in maintaining the household. ${ }^{10}$

Minahasa divorce among Christians are rare, but raw foster (living together) a lot going on. Similarly, Christians in Maluku and East Nusa Tenggara, divorce is rare but it applies to live together and polygamy are not official. But among the Kristen Batak, divorce is rare and living together is not a custom. In Lampung that native Muslim population, it turns coastal communities habitual easier divorce than people who are habitual pepadun environment.

Similarly, the state prior to the enactment of Law No. 1 in 1974 but now seems to be a divorce it is rare compared to the state in advance, because, of Law No. 11974 complicate the divorce. Divorce is not only due to the law and regulations but also due to the extent of the influence of the culture of shame and control of community In communities strong kinship ties difficult divorce occur than people who are weak kinship ties.

In general, according to customary law ideal, either breaking up the marriage because of death or divorce, bringing the legal effect of the position of husband and wife, for the maintenance,

9 Article 1 of Law No. 1 of 1974 About Marriage, 73

10 Muhammad Syaifuddin, Sri Turatmiyah, Annalisa Yahanan, 2013, Divorce Law, (Jakarta: Sinar Grafika,), 21 
education and status of children, to their families and relatives and to the joint property (property divorce), property congenital, property administration, inheritance or legacy. Everything was based on customary law which applies each, and there is no similarity between the indigenous peoples to one other. Although basically marriage was intended to forever, but sometimes there are specific causes that lead to marriage can not be forwarded so should The disconnect in the middle of the road or for attrition by itself, or in other words the divorce between husband and wife. ${ }^{11}$

In the Minang community marriage broke up because of death, in the case of marriage, the wife whose husband's death only recently allowed to remarry after being able period of time on the waiting period specified, while the husband that his wife's death can immediately mate again, in the case of children, to be borne by the parties either in maintenance, education, and funding, in terms of wealth, is entitled to the estate of a dead treasures.

After the enactment of the Law of marriage, of property in a marriage set in Article 35 paragraph (1) and (2) of the Act of marriage. What is different is part of the property which becomes joint property. In the Civil Code, all assets become property of husband and wife together. In the marriage law, which became the joint property is property acquired during the marriage, while property acquired before the marriage became an innate property of their respective husband and wife. Treasure congenital and acquired possessions that each as a gift or inheritance is under the control of each round the parties could not agree otherwise.

This is contrary to customary Minang inheritance system, it can be released from the kinship system adopted by indigenous people in Indonesia. Indigenous peoples of Indonesia embrace different religions, tribes, different beliefs, so this form of familial and kinship are different too. ${ }^{12}$

In customary law, community property is part of the marital property. Treasure marriage is a property that may be used by the husband and wife to defray the cost of their daily lives and their children.

A husband and wife as a unit with her children in the household or indigenous people called home. Thus, marital property is generally reserved for household purposes. Treasure marriage in customary law, according to Ter Haar Mohamad was quoted as saying by the Isna ${ }^{13}$ Wahyudi, can be divided into four kinds:

1. Assets acquired as a husband or wife inheritance or grants from their respective relatives and brought into the marriage

2. Assets acquired husband or wife for yourself as well as for services themselves before marriage or during marriage.

3. Treasure the time of marriage obtained by husband and wife as belonging together.

4. Treasure awarded to husband and wife together at the time of the wedding.

Marriage is a treasure worldly wealth to meet all household necessaries of life shall be distinguished from relatives treasure. It must be recognized that sometimes the line between marriage or Treasure friendly or treasure Relatives Family was very weak and not easily seen, but also sometimes very clear and unequivocal. So treasure marriage in general is intended

11 Soemiyati, 1997, Marriage Law Islam and the Constitution-Marriage Act, (Yogyakarta: Liberty), 105

12 Poesponoto, Soebekti, 1980, Principles and Sususnan Customary Law, Pradnya Paramita, Jakarta, Page54.

13 Mohamad Isna Wahyudi, 2006, "treasure together: Between Conception and Demands of Justice", Cakim MARI, PA Yogyakarta. 
first of all, for the household, the husband, wife and children to pay for expenses of everyday life.

Customary inheritance law in Indonesia can not be separated from the influence of different kinship structure of society. Customary inheritance law has its own style of a traditional nature public mind with the shape of the offspring patrilineal kinship system, matrilineal and parental or bilateral. At the same forms of kinship do not necessarily hold the same inheritance system. ${ }^{14}$

Benchmarks in the process of inheritance, so that the forwarding or distribution of inheritance can work in harmony, peace, and do not give rise to cross a dispute between the heirs to inheritance left by the testator. ${ }^{15}$ The system of inheritance according to the law of inheritance customs influenced by the structure of their community or kinship consisting of patrilineal system (kinship system drawn patrilineal), the matrilineal system which kinship system drawn matrilineal, the parental system or bilateral ie kinship system drawn by line father and mother ${ }^{16}$ in indigenous communities, the kinship system in the sense that the withdrawal of these lines, can be divided into two, namely draw lineage from one side only (unilateral), and draw lineage from both sides (bilateral). Further unilateral can be divided into two as well, namely fascinating lineage only from the male (patrilineal) only, and fascinating lineage only from the female (matrilineal) only. ${ }^{17}$

One system that is matrilineal system, a system that the community members draw up the lineage through the mother, the mother of the mother, kept up so found a woman as their ancestry. Legal consequences arising is all the family is the mother's family, as well as the heir of the family of the mother. Husband or father does not enter into the mother's family or not included in the wife's family. It can be said that the family system drawn from the mother's side, position women are more prominent than men in inheritance.

System of civil law in Indonesia that is pluralism (variegated), as well as the lack of unification in inheritance law in Indonesia, which is part of the civil law of Indonesia, so until now we are still using three systems of inheritance law that has existed since the former, namely customary inheritance law, Islamic inheritance law and inheritance law western civil Burgerlijk Wetboek(BW).

Inheritance law customary is also the rules that govern the process forward and divert items of property and goods that are not tangible objects from one human generation to the offspring ${ }^{18}$ Goodness inheritance system individually is the ownership of their respective heirs, it can be free master and own property to be used as part of capital life without the influence of other heirs.

The drawback of this system individually inheritance is inheritance and stretching it rupture of ties with family who may pose a desire to have a material personal and selfish. This individual inheritance system leads on lust are individualistic and materialistic, which will cause discord among the heirs. ${ }^{19}$

14 Understanding the Principles of Customary Law, 1998: Publisher Alumni, Bandung, Pg 198

15 F. Satriyo Wicaksono, 2011, Inheritance Law and the Right Way Easy Dividing Inheritance,Jakarta: Visimedia, Page 48

16 Ibid.p. 10

17 Soebakti, Poesponoto, 1960, Principles and Organization of Customary Law,Jakarta: Pradnya Paramita, hal.125

18 Supomo, 1987, Chapters On Customary Law, Jakarta, Pradnya Paramita, Pg. 79

19 Hiksyani Nurkhadijah, 2013, Systems Division ofInheritance, Thesis, University of Hasanuddin, Makassar, p. 20 
Customary inheritance law is customary law that contains provisions on the lines of the system and the principles of the law of inheritance, about the inheritance. Testator and the heir and show how the estate was transferred the control and ownership of the heir to the heir. Real inheritance law is the law of forwarding wealth from one generation to the offspring. ${ }^{20}$

The law of inheritance under customary law always is a problem actual Minang in discussions. It might be due to peculiar and unique when compared with the customary law system of inheritance from other areas in Indonesia. As has been stated, that the system kinship in Minang is an interesting system of maternal lineages were calculated according to the mother, the brother and sister, grandmother and his brethren, both men and women.

With such a system, then all children can only become an heir of his own mother, good for High Heritage treasure is treasure passed down from generations, as well as low property inheritance coming down from one generation.

Because matrilineal then indirectly all the treasures bequeathed to the daughter, if a family has a lot girl the inheritance equally divided then what about families who do not have a daughter who means the lineage in the family was disconnected because no aka dang pass, based on custom rules that apply inheritance left to the next of kin are still one tribe. Although the men are not on an inheritance which is usually mapped fields and lading, the male-lakisebagai niniak mamak (om) still have rights as decision makers, so no bias girl who receives inheritance niniak mamak sell it without consent.

If sassy sell inherited property without permission from mamak niniak ready to be ostracized even used to dealing with the police. But sometimes there are also the men who get the estate, usually comes from a family does have a lot inheritance so that the bias distributed to the men of course with far fewer servings.

\section{CONCLUSION}

It can be concluded that the Minang community also recognize the waiting period or known'Iddah for these women enshrined in Law No. 1 Year 1974 about marriage in article 38, article 39 and article 41. In the case of divorce Minangkabau matrilineal system load that is all in the maternal lineage or women this conflicts with Law 1 of 1974 about marriage in which the legislation contains common property inheritance but also in matrilineal societies in Minang, is closely related to the kinship system attractive maternal lineage.

Minang kinship system is an interesting system of maternal lineage is calculated according to the mother, the brother and sister, grandmother and his brethren, both men and women. With such a system, then all children can only become an heir of his own mother, good for High Heritage treasure is treasure passed down from many generations, and treasure the treasure Heritage Low down from one generation. Limit with congenital treasures while in Minang decision marital community property owned by a wife that is matrilineal and not in the joint as in legislation.

\section{REFERENCE}

F. Satriyo Wicaksono, 2011, Hukum Waris Cara Mudah dan Tepat Membagi Harta Warisan, Jakarta : Visimedia.

Hiksyani Nurkhadijah, 2013, Sistem Pembagian Harta Warisan, Skripsi, Universitas Hasanudin, Makassar.

20 Hilman Hadikusuma, 1983, Customary Inheritance Law,Bandung: Alumni, p. 19. 
Putri Maha Dewi, SH, MH : Distribution Of Heritage And Culture Iddah Minang Divorce ...

Hilman Hadikusuma, 1983, Hukum Waris Adat, Bandung: Alumni,. ,2007, Hukum Perkawinan Indonesia, Bandung: CV. Mandar Maju.

H. Rusdi Malik, 2010, Memahami Undang-Undang Perkawinan, Jakarta : Penerbit Universitas Trisakti,.

Mohamad Isna Wahyudi, 2006, “Harta bersama: Antara Konsepsi dan Tuntutan Keadilan”, Cakim MARI, PA Yogyakarta.

Muhammad Syaifuddin, Sri Turatmiyah, Annalisa Yahanan, 2013, Hukum Perceraian, Jakarta: Sinar Grafika.

Poesponoto, Soebekti, 1980, Asas-Asas dan Susunan Hukum Adat, Pradnya Paramita, Jakarta.

Pokok-Pokok Pengertian Hukum Adat, 1998 : Penerbit Alumni, Bandung.

Riduan Syahrani, 1989, Seluk Beluk dan Asas-Asas Hukum Perdata, CV Alumni, Bandung.

Subekti, 1985, Pokok - Pokok Hukum Perdata, Jakarta: PT. Internusa,

Soebakti, Poesponoto, 1960, Asas-asas dan Susunan Hukum Adat, Jakarta : Pradnya Paramita,.

Soemiyati, 1997, Hukum Perkawinan Islam dan Undang - Undang Perkawinan, Liberty Yogyakarta:.

Soepomo, 1987, Bab-Bab Tentang Hukum Adat, Jakarta, Pradnya Paramita,.

Pasal 1 Undang-Undang Nomor 1 Tahun 1974 Tentang Perkawinan

http://www.hukumonline.com/klinik/detail/t4f3b41b9d2da/dampak-perceraian-terhadapharta-bersama-15/06/2016 12:30.

https://www.boyyendratamin.com/2013/02/antara-adat-minangkabau-dan-hukumadat.html14/06/2016 12:02

http://bundokandung.wordpress.com/2010/01/31/hukum-adat-di-minangkabau/14/06/2016 $11: 12$ 